\title{
Zooxanthellae loss as a bioassay for assessing stress in corals
}

\author{
Ross J. Jones* \\ Department of Biochemistry, James Cook University, Townsville, Queensland 4811, Australia
}

\begin{abstract}
Branch tips from colonies of a staghorn coral Acropora formosa were exposed to elevated concentrations of copper in order to examine the potential of the 'bleaching' response as a means of assessing stress in corals. Two identical toxicity tests were conducted over $48 \mathrm{~h}$ using 2 colonies with naturally different algal (zooxanthellae) densities. The tips from both colonies bleached in proportion to the copper concentrations, through loss of zooxanthellae to the surrounding water A higher incidence of mortality was observed in tips from the colony with fewer zooxanthellae. During the tests, control corals lost zooxanthellae at a rate of $<1 \%$ of the algal standing stock $\mathrm{d}^{-1}$, zooxanthellae release from both control and experimental corals occurred $2 \times$ faster during the daytime than night time, and the number of zooxanthellae appearing as doublets (the mitotic index) was 5 to $8 \times$ higher in zooxanthellae released from the corals' tips than inside the tips (in hospite) at the end of the experiment. The implications of these findings for future toxicity tests using the bleaching response, and for using changes in the number of zooxanthellae appearing as doublets to assess stress are discussed. Results suggest (1) that loss of zooxanthellae can be used within the framework of a standardised laboratory-based bioassay with universal integrity for assessing stress in zooxanthellate corals, and (2) that inherent differences in the densities of zooxanthellae between coral colonies are likely to affect the outcome of experiments using the bleaching response and of other biochemical or physiological stress responses.
\end{abstract}

KEY WORDS: Bleaching · Copper · Stress assessment - Zooxanthellae · Acropora formosa

\section{INTRODUCTION}

In a review of stress assessment in hard corals, Brown \& Howard (1985) conclude '...there is little convincing evidence in the literature reviewed so far of a sensitive laboratory bioassay to any pollutant tested...'. If a suitable technique is available, then it can provide (1) water quality criteria for reefal areas (e.g. for heavy metals), (2) an initial assessment or 'screening' of the toxicity of potential toxicants which may be introduced to reefal waters (e.g. anti-foulants, oil dispersants, drilling fluids and produce formation water from the oil and gas industry), and (3) matrices of hard data useful for reef management strategies and to underpin decision making processes.

\footnotetext{
- Present address: School of Biological Sciences, Building A08 University of Sydney, NSW 2006. Australia.

E-mail: rjones@bio.usyd.edu.au
}

Coral bleaching has been suggested as a potential physiological response which can be used to assess stress (Brown 1988). Corals gain most of their colouration from the photosynthetic pigments of the symbiotic algae (zooxanthellae) in their tissues. The term 'bleaching' has been used to describe the change of colouration as the white skeleton becomes visible through the relatively transparent animal tissues. This may occur following a decrease in the number of algae in the tissues (Yonge \& Nicholls 1931, Hoegh-Guldberg \& Smith 1989a), a decrease in the photosynthetic pigments of the algae (Hoegh-Guldberg \& Smith 1989a), or both (Kleppel et al. 1989, Porter et al. 1989). Corals may also discolour if the tissues become strongly retracted exposing the naked coral skeleton (Brown et al. 1994). Such bleaching may occur without any loss of photosynthetic pigments from the coral's tissues.

Bleaching (as a decrease in photosynthetic pigments in the tissues) is an ecologically significant response, 
resulting in a loss of photosynthetic potential (Porter et al. 1989), a cessation or reduction of growth (Jokiel \& Coles 1977. Porter et al. 1989, Goreau \& MacFarlane 1990), and a decrease in reproductive output (Szmant \& Gassman 1990)

Bleaching has been observed in response to a diverse range of stresses, see Brown \& Howard (1985) for a review. In more recent studies loss of zooxanthellae has been documented in corals exposed to elevated concentrations of iron (Harland \& Brown 1989), lowered seawater temperatures (Muscatine et al. 1991, Gates et al. 1992), ultraviolet (UV) light (Gleason \& Wellington 1993), terpenoids (secondary metabolites of soft corals, Aceret et al. 1995) and cyanide (author's unpubl. results).

Bleaching is usually considered to be the initial response to a stress that may eventually kill a coral. There are numerous observations of recovery of pigmentation by bleached corals (Yonge \& Nicholls 1931, Coles \& Jokiel 1978, Hayes \& Bush 1990, Szmant \& Gassman 1990, Fitt et al. 1993). Consequently, bleaching may provide a tool for grading the response of corals to natural and un-natural stress in a range between 'no effect' and 'lethal'.

In the present study the bleaching response is evaluated as a means of assessing stress in corals within the framework of a standardised laboratory-based bioassay. The heavy metal copper was chosen for the tests as it is a common marine pollutant. Some inputs to reefal environments include mining and smelting operations (Harland \& Brown 1989, Denton \& Heitz 1990), coastal run-off (Guzmán \& Jiménez 1992), sacrificial anodes on boats (McConchie \& Harriott 1992), and the marine disposal of municipal solid waste incinerator ash (Knap et al. 1991). Small branch tips of a staghorn coral Acropora formosa were exposed to elevated copper concentrations and the nature, processes and patterns of bleaching examined. Two identical toxicity tests were conducted using tips from neighbouring colonies containing different zooxanthellae densities (Jones 1995) to examine intraspecific variability of bleaching. The number of zooxanthellae appearing as doublets (the zooxanthellae mitotic index, MI) is also examined as a potential means of assessing stress.

\section{MATERIALS AND METHODS}

Experiments were conducted using 2 colonies of a staghorn coral Acropora formosa (Dana 1846) located at 5 to $6 \mathrm{~m}$ depth on the inshore fringing reefs of Nelly

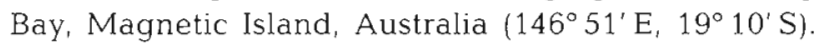
Colonies were separated by a distance of $\sim 4 \mathrm{~m}$. The terminal 40 to $50 \mathrm{~mm}$ portion of 35 brown-tipped branches (see Oliver 1984) were cut from each of the colonies using surgical bone forceps. The basal 2 to $5 \mathrm{~mm}$ of each tip was wrapped with a thin layer of modelling clay. Tips were then inserted into small acrylic cylinders, and slotted into acrylic racks next to the parent colonies for a 14 to $20 \mathrm{~d}$ recovery period. Experiments commenced when the tips had begun to deposit a small 1 to $2 \mathrm{~mm}$ 'skirt' of lightly calcified coenosarc tissue around the modelling clay.

Five branch tips from the pool of prepared tips from each colony were exposed to copper concentrations of $5,10,20,40$ or $80 \mu \mathrm{g} \mathrm{l}^{-1}$ for $48 \mathrm{~h}$ in individual $150 \mathrm{ml}$ glass beakers. Both experiments (Tests 1 and 2) were started at 12:00 h. In a subsequent experiment (Test 3) branch tips from 1 of the colonies were exposed to $5 \mu \mathrm{g}$ $1^{1}$ copper for $96 \mathrm{~h}$. This experiment was started at 18:00 h. Three separate controls were used during the toxicity tests. In the first control, referred to as the parent colony control (PC), 5 brown-tipped branches tips were excised from each of the parent colonies at 3 to 5 wk intervals for 6 mo after the tests. In the second control, referred to as the handling controls $(\mathrm{HC}), 5$ brown-tipped branches were randomly selected from the pool of prepared coral tips immediately before each experiment. In the third control, referred to as the test control (TC), 5 brown-tipped branches were exposed to ambient seawater only during the tests. Algal densities were determined in each of the separate controls.

Seawater used for making test solutions was collected from the reef each morning and filtered through Whatman GF/C filters. Required test concentrations were made by adding a stock solution of $\mathrm{Cu}_{2} \mathrm{SO}_{4}$ in distilled water. $120 \mathrm{ml}$ of either copper or control solution was placed in individual acid washed glass beakers which were then placed inside a water bath receiving a continuous supply of seawater pumped from the reef. Each beaker was supplied with air from a network of aquarium pumps. A $3 \mathrm{~mm}$ thick sheet of plexiglass (cut off $\sim 400 \mathrm{~nm}$, Lesser \& Shick 1989) was placed above the beakers to protect against UV light, and to provide cover against rainfall. A double layer of $80 \%$ (absorption) shade cloth was used to reduce light levels experienced by the corals (Fig. 1). Light levels during the tests were recorded with a Lambda Li-Cor $190 \mathrm{SA}$ underwater sensor mounted above the test containers. Mean light intensity over $10 \mathrm{~min}$ intervals was recorded onto a Li-Cor data logger (Fig. 1). Water temperatures were measured with a thermometer immersed within the water bath and compared to seawater temperatures on the reef slope $(5 \mathrm{~m})$ measured by in situ waterproof platinum RTD thermocouple sensors (accuracy $\pm 0.1^{\circ} \mathrm{C}$ ) and recorded onto data loggers (Stobart 1994). Water temperatures during both $48 \mathrm{~h}$ toxicity tests $\left(\bar{x}=24.6^{\circ} \mathrm{C}\right.$ during Test $1,23.0^{\circ} \mathrm{C}$ during 


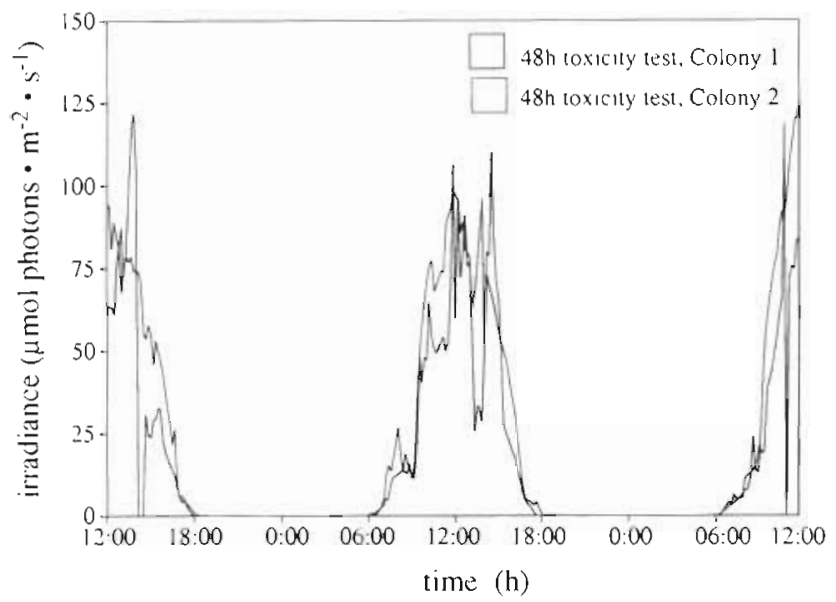

Fig. 1 Mean irradiance ( $\mu$ mol photons $\mathrm{m}^{-2} \mathrm{~s}^{-1}$ ) during $48 \mathrm{~h}$ toxicity tests

Test 2) were similar to in situ temperatures on the reef slope at Magnetic Island $\left(\bar{X}=24.9^{\circ} \mathrm{C}\right.$ during Test 1 . $22.3^{\circ} \mathrm{C}$ during Test 2, Stobart 1994).

At the start of each experiment the prepared coral tips were randomly allocated to the beakers containing the test solutions. Every $6 \mathrm{~h}$ the incubation water in each beaker was renewed. During this process 2 to $3 \mathrm{ml}$ of the incubation water was squirted against the coral holder to resuspend any released zooxanthellae that may have settled. The coral was then transferred to a $500 \mathrm{ml}$ 'holding' beaker containing clean unfiltered aerated seawater Approximately 20 to $30 \mathrm{ml}$ of the incubation water was then squirted against the sides of the incubation beaker to remove zooxanthellae that may have adhered to the glass surface. The incubation water (containing any released zooxanthellae) was poured into containers and fixed with $5 \mathrm{ml}$ of $40 \%$ buffered formalin. A fresh test solution was then placed in each incubation beaker and the coral tip transferred back.

At the end of the second $48 \mathrm{~h}$ toxicity test (Test 2), 3 randomly selected coral tips from each test concentration were transferred back to the reef and placed in the acrylic racks beside the parent colonies. The tips were examined for colour and appearance after 1, 2, 3, 6 and $10 \mathrm{wk}$. All other tips were frozen.

Zooxanthellae released from the corals during Test 2 were concentrated by centrifuging. The containers holding the fixed incubation water were shaken vigorously, and the incubation water was then homogenised for $15 \mathrm{~s}$ with a blender. A $100 \mathrm{ml}$ aliquot was centrifuged at $3000 \times g$ for $15 \mathrm{~min}$ and the supernatant discarded, leaving an algal pellet. The algal pellet was then re-suspended in a $2 \%$ formalin solution and the number of zooxanthellae counted with a hemacytometer (10 replicate counts) The number of zooxanthel- lae released during the incubation was determined after correcting for the volume centrifuged and the addition of formalin.

Rates of release of zooxanthellae from the coral tips were analysed over 6, 12 and $24 \mathrm{~h}$ periods (see 'Results'). When rates of release were examined over 12 and $24 \mathrm{~h}$ periods, algal pellets produced after centrifuging the incubation water from successive $6 \mathrm{~h}$ incubations were pooled and then counted. Rates of release over different time periods were normalised to a $24 \mathrm{~h}$ basis, and then expressed as zooxanthellae released polyp ${ }^{-1}$. The zooxanthellae specific expulsion rate $\left(\mu_{x}\right)$ was calculated using the equation described in Hoegh-Guldberg et al. (1987).

Tissues of the corals were removed from the skeleton with a jet of re-circulated $0.45 \mu \mathrm{m}$ membrane-filtered seawater (FSW) using a WaterPik ${ }^{\mathrm{TM}}$ (Johannes \& Wiebe 1970). Two separate washes of 60 to $80 \mathrm{ml} \mathrm{FSW}$ were used on each tip, and $20 \mathrm{ml}$ was used to rinse the coral skeleton, WaterPik ${ }^{\mathrm{TM}}$ reservoir, and flush the WaterPik ${ }^{\mathrm{TM}}$ pump after each wash. Successive washes produced from the stripping and cleaning processes were pooled, homogenised for 10 to $20 \mathrm{~s}$, and the volume recorded. The number of zooxanthellae in each of two $10 \mathrm{ml}$ subsamples of the homogenate was determined from 10 replicate counts using a hemacytometer. An average of the 2 subsamples was used to determine the total zooxanthellae in the tips. Zooxanthellae were normalised to the number of polyps, recorded by visual census of calices on the branch (Muscatine et al. 1991).

The number of zooxanthellae appearing as doublets (mitotic index, MI) in the tips (in hospite) at the end of the first $48 \mathrm{~h}$ toxicity test (Test 1 ), and the zooxanthellae released into the incubation water during the last $6 \mathrm{~h}$ incubation period of the test, was determined from each of 2 samples of 1000 algae. Zooxanthellae were examined at $400 \times$ magnification and scored as dividing if they were present as doublets. The zooxanthellae specific growth rate $\left(\mu_{z}\right)$ in the control tips at the end of the test was calculated using the equation outlined in Wilkerson et al. (1983).

For chlorophyll analyses, two 10 to $20 \mathrm{ml}$ subsamples of the tissue homogenate were filtered through Whatman GF/C: glass fibre filters. Each filter was then cut into small pieces with dissecting scissors and homogenised for $30 \mathrm{~s}$ using a tissue homogeniser. Chlorophylls were extracted from the filters with $10 \mathrm{ml}$ of $90 \%$ acetone for $24 \mathrm{~h}$ in a freezer. The extracts were then centrifuged at $3000 \times g$ for 3 min to remove filter fibres from suspension, and the absorbances of the supernatant solutions were read on a Hitachi UB2000 spectrophotometer. The equations of Jeffrey \& Humphrey (1975) were used to calculate the weight of chlorophyll a (hereafter $\mathrm{chl}$ a) and an average of the 2 
subsamples used to provide a final estimate of the total chl $a$ in each tip.

The ability of the tissue stripping process to remove the coral tissues from the skeleton (hence extract the zooxanthellae) was determined with a number of bleached and unbleached coral tips. After the tissues had been stripped the coral skeletons were digested in 2 to $3 \mathrm{ml}$ of $5 \% \mathrm{HCl}$ and the digest centrifuged at 3000 $\times g$ for 5 min leaving a small algal pellet (representing zooxanthellae still remaining in the skeleton after tissue stripping). The supernatant was then discarded, the algal pellet re-suspended in $0.45 \mu \mathrm{m}$ FSW, and the process repeated until the $\mathrm{pH}$ of the solution approximated 8. Zooxanthellae were then counted with a hemacytometer (10 replicate counts), and compared to the algal densities stripped from the skeleton with the WaterPik ${ }^{\mathrm{TM}}$

Data are presented as means $\pm 95 \%$ confidence intervals (CI). Type I ANOVA $(\alpha=0.05$, JMP 1994) was used to examine treatment effects. Dunnett's test of significance was used to compare the nature of significant differences by comparing treatment and control means. Prior to all analysis assumptions of normality (Shapiro-Wilks test) and homogeneity of variance (Welch's test) were tested. MI data were first subjected to arcsine transformation before statistical analysis.

\section{RESULTS}

\section{Toxicity tests conducted over $48 \mathrm{~h}$}

Branch tips of Acropora formosa from Test 1 exposed to $80 \mu \mathrm{g} \mathrm{l}^{-1}$ copper turned from a normal brown colour to a lighter colour within $6 \mathrm{~h}$, and to a light tan colour by $24 \mathrm{~h}$. Tips exposed to $40 \mu \mathrm{g} \mathrm{l}^{-1}$ copper began to discolour after $24 \mathrm{~h}$. Between 24 and $36 \mathrm{~h}$, all tips exposed to $80 \mu \mathrm{gl}^{-1}$ copper died, and 4 of the 5 tips in the $40 \mu \mathrm{g}$ $1^{-1}$ treatment died. In Test 2 (conducted with tips from a separate neighbouring colony), the tips also bleached at the highest $\left(80 \mu \mathrm{g} \mathrm{l}^{-1}\right)$ copper concentration. However, discolouration appeared to be less extensive, and no mortalities were observed at any test concentration.

Colour loss was uniform across the tips during the bleaching process. However, in some corals exposed to 10 and $20 \mathrm{\mu g} \mathrm{l}^{-1}$ copper preferential loss of colour was observed from corallites, giving the corals a speckled appearance. In the 40 and $80 \mu \mathrm{g} \mathrm{l}^{-1}$ treatments zooxanthellae were observed settled on the modelling clay surrounding the bases of the coral tips. Coral polyps were partially contracted within the corallites during the tests and only the ends of the tentacles could be observed protruding from the calices. Polyps responded to tactile stimuli during the bleaching process and fully retracted when touched with a pipette tip.

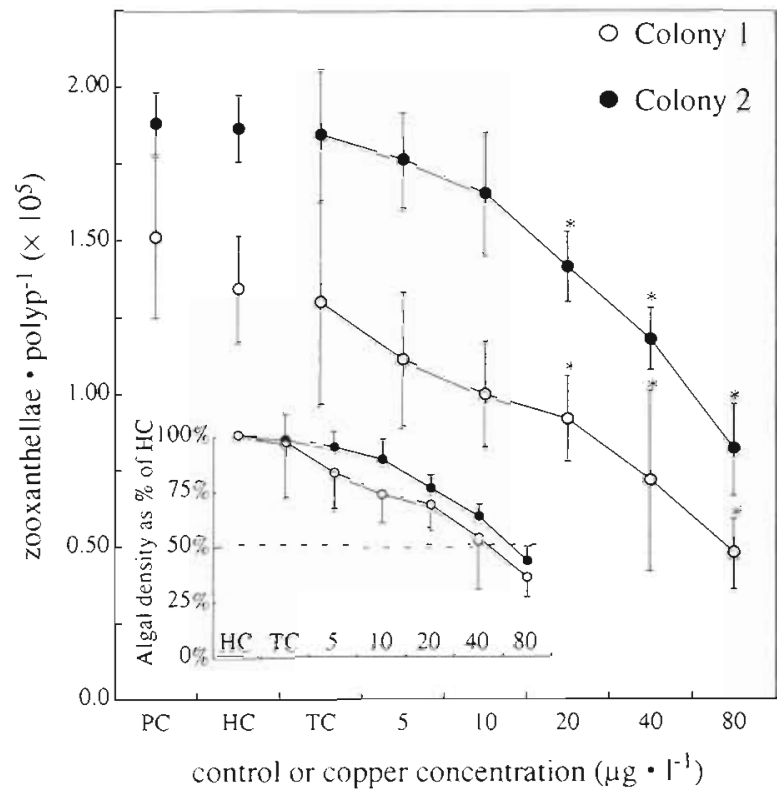

Fig. 2. Acropora formosa. Zooxanthellae density at the end of the 48 h toxicity tests, expressed as $\bar{x}$ zooxanthellae polyp ${ }^{-1} \pm$ $95 \%$ confidence intervals, $\mathrm{CI}(\mathrm{n}=5$ tips). $\mathrm{HC}$ : handling control, TC: test control, PC: parent colony (see Materials and methods' for explanation). For the first copper toxicity test (Test 1) (open circles) the zooxanthellae density at $80 \mu \mathrm{g} \mathrm{I}^{-1}$ represents those present after 30 to $36 \mathrm{~h}$ at which point the corals died. *Significant differences from the HC (ANOVA, $\mathrm{p}<0.05$ ). Inset, zooxanthellae densities in each treatment concentration expressed as a \% of the densities in the respective $\mathrm{HC}$

The tissue stripping process with the WaterPik ${ }^{1 M}$ removed $98.3 \pm 0.5 \%(\bar{x} \pm 95 \% \mathrm{Cl}, \mathrm{n}=18$ branch tips $)$ of the available zooxanthellae from both bleached and unbleached branch tips.

The zooxanthellae density in the first colony (PC, $1.5 \pm 0.3 \times 10^{5}$ zooxanthellae polyp ${ }^{-1}, \bar{x} \pm 95 \% \mathrm{CI}, \mathrm{n}=6$ sampling times) was significantly different from that in the second colony $\left(1.9 \pm 0.1 \times 10^{5}\right.$ zooxanthellae polyp $\mathrm{p}^{-1}$, Student's t-test, $\mathrm{p}<0.05$, Fig. 2). There were no significant differences in the algal densities among the $\mathrm{PC}, \mathrm{HC}$ and $\mathrm{TC}$ for each colony during the tests (ANOVA, $p>0.05$, Fig. 2). In both experiments, algal densities in tips exposed to 20,40 and $80 \mu \mathrm{g} \mathrm{l}^{-1}$ copper were significantly different from the HC (ANOVA, p < 0.05, Fig. 2).

There were no significant differences in the algal chl a concentration between treatments in the experiment with the first colony (Fig. 3). In the experiment with the second colony, the algal chl a concentration was significantly different from the $\mathrm{HC}$ in the 40 and $80 \mu \mathrm{g} \mathrm{l}^{-1}$ treatments (ANOVA, $p<0.05$, Fig. 3, lower graph)

Corals returned to the reef after the second toxicity test regained their colouration within 6 wk, except 2 


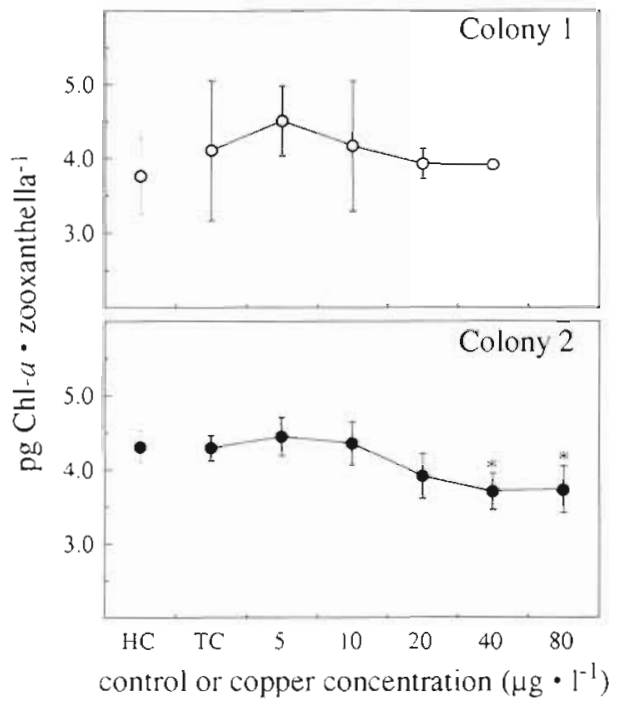

Fig. 3. Acropora formosa. Algal chl a concentration (pg chl a zooxanthella ${ }^{-1}, \bar{x} \pm 95 \% \mathrm{Cl}, \mathrm{n}=5$ tips) in the first colony (upper graph; Test 1) and second colony (lower graph; Test 2) at the end of the $48 \mathrm{~h}$ toxicity tests. Due to mortalities during the first copper toxicity test (see text) no data is available for the $80 \mu \mathrm{gl}^{-1}$ copper treatment, and data from only 1 coral is available for the $40 \mu \mathrm{g} \mathrm{l}^{-1}$ treatment. $*$ Significant difference from TC (ANOVA, $p<0.05$ )

of the tips exposed to the $40 \mu \mathrm{g} \mathrm{l}^{-1}$ solutions which still appeared lighter than the parent colony after $10 \mathrm{wk}$.

The rate of release of zooxanthellae from the TC averaged $4.1 \pm 3.6 \times 10^{2}$ cells polyp ${ }^{-1} 24 \mathrm{~h}^{-1}(\bar{x} \pm 95 \%$ $\mathrm{Cl}, \mathrm{n}=5$ ), similar to rates of release from tips exposed to $5 \mu \mathrm{g} \mathrm{l}^{-1}$ copper (Fig. 4). Rates of release of zooxanthellae were significantly different than from the TC in corals exposed to 20 and $40 \mu \mathrm{g} \mathrm{l}^{-1}$ copper (ANOVA, $\mathrm{p}<$ 0.05, Fig. 4).

The rate at which zooxanthellae were released from the corals $\left(\mu_{\mathrm{x}}\right)$ exposed to ambient seawater (TC) was $40 \%$ of the rate at which zooxanthellae were added to the population from algal division $\left(\mu_{z}\right)$.

The rate of release of zooxanthellae was examined over $6 \mathrm{~h}$ intervals during the last $24 \mathrm{~h}$ of Test 2 . In all treatments the rate of release of zooxanthellae fell during the first dark period (18:00 to 0:00 h), fell again during the second dark period (0:00 to 06:00 h), and then increased markedly during the morning $6 \mathrm{~h}$ light period (06:00 to 12:00 h, Fig. 5).

There were no significant differences between the MI of zooxanthellae in the control corals (TC) and those in the copper treatments (ANOVA, $p>0.05$, Fig. 6). The MI of zooxanthellae released from the corals during the last $6 \mathrm{~h}$ incubation period was 5 to $8 x$ higher than the MI of zooxanthellae in hospite at the end of the experiment.

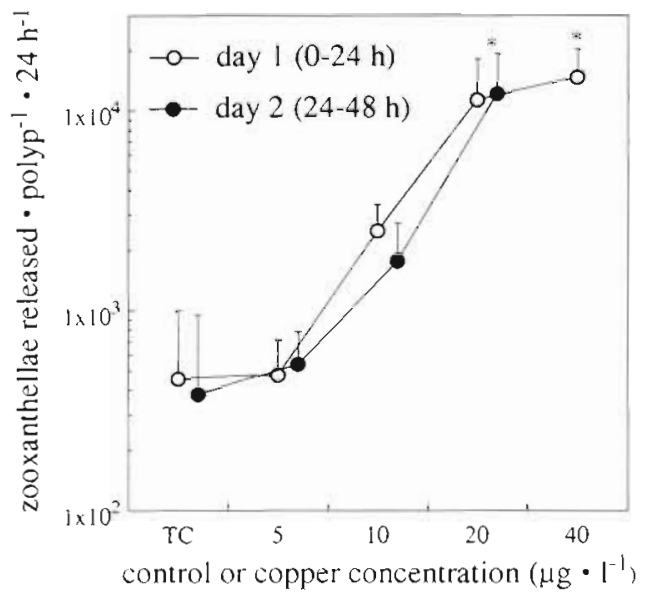

Fig. 4. Acropora formosa. Rate of release of zooxanthellae from coral tips over $24 \mathrm{~h}$ periods, expressed as $\bar{x}$ cells released polyp ${ }^{-1} 24 \mathrm{~h}^{-1} \pm 95 \% \mathrm{CI}(\mathrm{n}=5$ tips). Note log scale on $y$-axis. *Significant difference from TC control (ANOVA, $p<0.05$ )

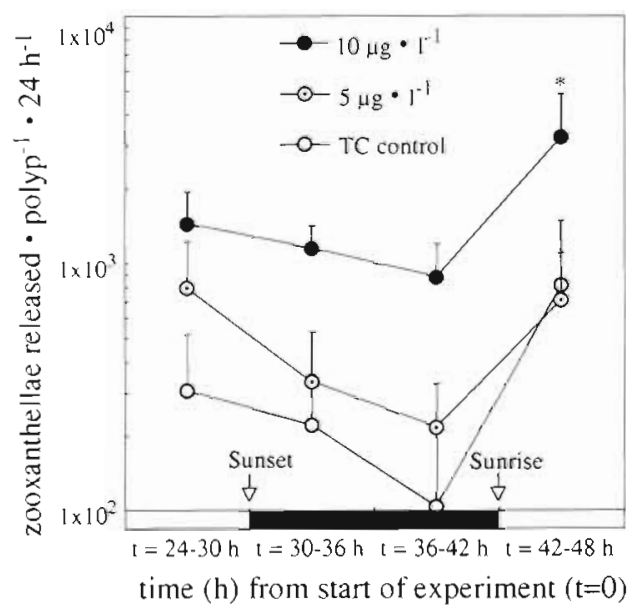

Fig. 5. Acropora formosa. Rate of release of zooxanthellae over $6 \mathrm{~h}$ periods during the last $24 \mathrm{~h}$ of Test 2, expressed as $\bar{x}$ cells released polyp $p^{-1} 24 \mathrm{~h}^{-1} \pm 95 \% \mathrm{CI}(\mathrm{n}=5 \mathrm{tips})$. Note $\log$ scale on $y$-axis. *Significant difference from TC control (ANOVA, $\mathrm{p}<0.05$ ). Each $6 \mathrm{~h}$ period occurred either in the light or dark, the first period lasting from 12:00 to 18:00 h, etc. Black bar indicates hours of darkness

\section{Toxicity test conducted over $96 \mathrm{~h}$}

There was no significant difference in the colour of the corals during the experiment (Test 3), or in the algal densities between treatments at the end of the experiment $\left[\mathrm{PC}=1.5 \pm 0.3 \times 10^{5}\right.$ zooxanthellae polyp ${ }^{-1}$ $(\bar{x} \pm 95 \% \mathrm{CI}, \mathrm{n}=6$ sampling times $), \mathrm{HC}=1.3 \pm 0.2 \times 10^{5}$ zooxanthellae polyp ${ }^{-1}, \mathrm{TC}=1.1 \pm 0.2$ zooxanthellae polyp $\mathrm{p}^{-1}, 5 \mu \mathrm{g} \mathrm{l}^{-1}=1.3 \pm 0.2$ zooxanthellae polyp ${ }^{-1}$, ANOVA, $p>0.05]$. Polyps appeared partially expanded during the experiment and contracted when touched with a pipette tip. 


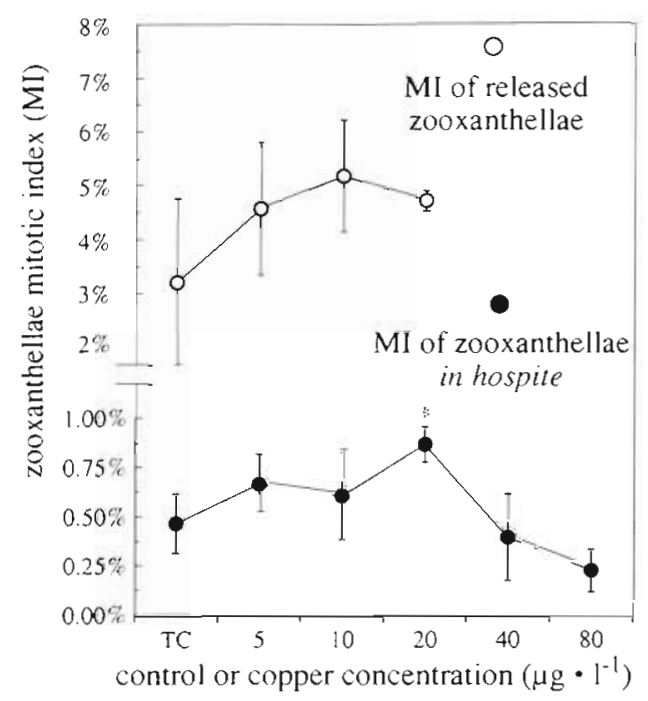

Fig. 6. Acropora formosa. Mitotic index (MI) of zooxanthellae remaining in coral tissues at the end of the 48 h toxicity test, and of zooxanthellae released from the corals in the last $6 \mathrm{~h}$ of the test. Each value represents the $\bar{x}$ cells released polyp ${ }^{-1}$ $24 \mathrm{~h}^{-1} \pm 95 \% \mathrm{Cl}$ ( $\mathrm{n}=5$ tips). $*$ Significant difference from TC (ANOVA, $p<0.05$ )

The mean daily rate of release of zooxanthellae from corals exposed to $5 \mu \mathrm{g} \mathrm{l}^{-1}$ copper $\left(3.4 \pm 1.5 \times 10^{3}\right.$ cells polyp $\mathrm{p}^{-1} 24 \mathrm{~h}^{-1}, \bar{x} \pm 95 \% \mathrm{CI}, \mathrm{n}=6$ ) was significantly different from the rate of release from control corals $(0.9 \pm$ $0.3 \times 10^{3}$ cells polyp ${ }^{-1} 24 \mathrm{~h}^{-1}, \bar{x} \pm 95 \% \mathrm{CI}, \mathrm{n}=6$, ANOVA, $p<0.05$, Fig. 7). In the control corals the rate of release of zooxanthellae during the daytime periods was $2 \times$ higher than during the night time periods. In corals exposed to $5 \mu \mathrm{g} \mathrm{I}^{-1}$ copper, a high initial release of zooxanthellae was observed in the first dark period $\left(7.5 \pm 5.0 \times 10^{3}\right.$ cells polyp $\left.{ }^{-1} 24 \mathrm{~h}^{-1}\right)$; however, there was a gradual return to a day/night rhythm of algal release as the experiment progressed (Fig. 7). Algal release rates were also analysed over $6 \mathrm{~h}$ intervals during the daytime periods of the $96 \mathrm{~h}$ test.

\section{DISCUSSION}

Branch tips of a staghorn coral Acropora formosa bleached (discoloured) during exposure to elevated concentrations of the heavy metal copper. The discolouration occurred through loss of zooxanthellae to the surrounding water, although decreases in algal chl a concentrations were measured in one of the tests in corals exposed to the higher copper concentrations. Bleached tips returned to the reef after the experiment gradually recovered their colouration, suggesting the loss of zooxanthellae observed during the studies was a sublethal response.

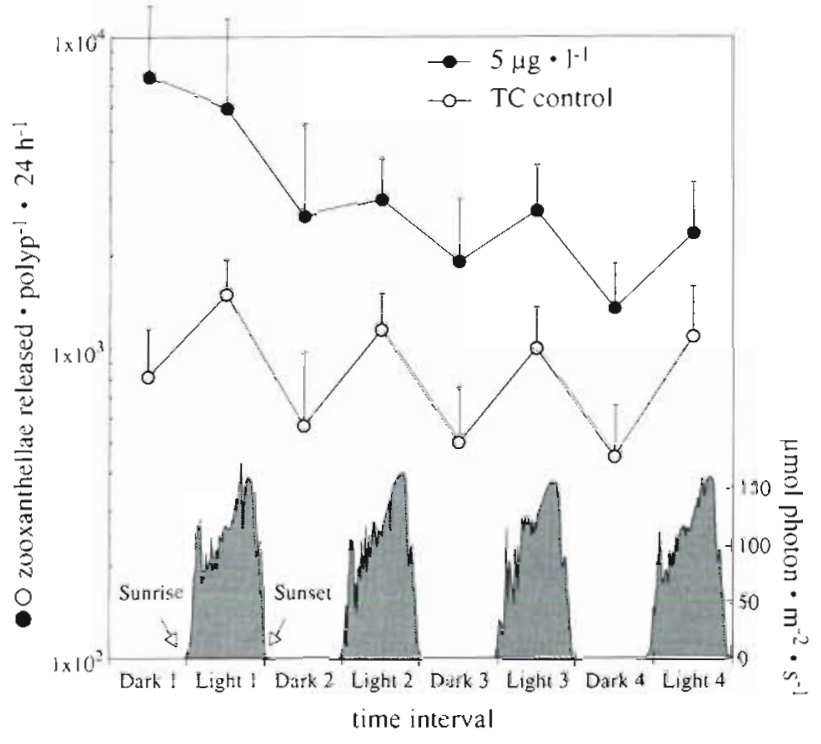

Fig. 7 Acropora formosa. Rate of release of zooxanthellae over $12 \mathrm{~h}$ periods during the $96 \mathrm{~h}$ toxicity test, expressed as $\bar{x}$ cells released polyp ${ }^{-1} 24 \mathrm{~h}^{-1} \pm 95 \% \mathrm{Cl}, \mathrm{n}=6$ tips. Note log scale on primary $y$-axis. Each $12 \mathrm{~h}$ period occurred exclusively in the light or the dark, the first dark period lasting from 18:00 to 06:00 h, etc. Secondary $y$-axis shows irradiance levels ( $\mu$ mol photon $\mathrm{m}^{-2} \mathrm{~s}^{-1}$ ) during the toxicity test

Bleaching of corals following exposure to heavy metals has been described before. Pocillopora damicornis and Montiporra verrucosa discoloured during exposure to $10 \mu \mathrm{g} \mathrm{I}^{-1}$ copper, and died during exposure to $100 \mu \mathrm{g} \mathrm{l}^{-1}$ copper (Evans 1977). A visual gradation of colour loss has also been observed in $M$. verrucosa following exposure to copper concentrations ranging from 10 to $50 \mathrm{\mu g} \mathrm{l}^{-1}$ (Howard et al. 1986). Decreases in algal density have been measured in a colony of Porites lutea exposed to elevated iron concentrations (Harland \& Brown 1989); the algal pigment concentration was not measured during that study.

The zooxanthellae released from the corals appeared morphologically intact, with no evidence of vacuolisation or disintegration of organelles. A significant proportion of the zooxanthellae in the expelled population were in the process of dividing (see below), also suggesting the zooxanthellae were functionally intact when released. Occasionally, mis-shapen redbrown objects 3 to $4 \mu \mathrm{m}$ in diameter were observed being expelled with the healthy zooxanthellae. These have been interpreted as degenerate (pycnotic) zooxanthellae (Yonge \& Nicholls 1931, Trench 1974). Due to inherent variability in the presence and number of pycnotic cells, degenerate zooxanthellae were not counted.

Zooxanthellae were released from control corals at a rate of less than $1 \%$ of the algal standing stock $\mathrm{d}^{-1}$. Similar algal release rates have been described for 
other corals: $0.1 \%$ of the algal standing stock $\mathrm{d}^{-1}$ for Stylophora pistillata in the Red Sea (Hoegh-Guldberg et al. 1987), and S. pistillata and Seriatopora hystrix from the GBR (Hoegh-Guldberg \& Smith 1989a), and $\sim 1 \%$ and $>1 \%$ for Pocillopora damicornis from Hawail (Muscatine et al. 1991, Stimson \& Kinzie 1991). The rate at which zooxanthellae were released from the coral tips $\left(\mu_{x}\right)$ was less than the rate at which cells were added to the populations by algal division $\left(\mu_{z}\right)$. Zooxanthellae produced from algal division in excess of those released from the coral may either be taken up by newly formed endodermal cells (i.e. from radial growth or growth at the base of the coral tips). or used to balance the loss of pycnotic zooxanthellae. The low level loss of zooxanthellae may represent the release of excess or 'supernumerary' zooxanthellae. Alternatively, zooxanthellae may be released as a result of necrosis, apoptosis (programmed cell death), or adhesion dysfunction of algal bearing host endodermal cells (Gates et al. 1992, Jones \& Yellowlees 1996).

The release of zooxanthellae from control corals occurred $2 \times$ faster during the daytime than night time (Fig. 7). Diel patterns of zooxanthellae release, also with twice as many zooxanthellae released during the daytime than night time, have been reported for colonies of Pocillopora damicornis in Hawail (Stimson \& Kinzie 1991). It is unlikely that the diel patterns of algal release observed in these studies are related to contraction and expansion patterns of the polyps, as they remained partially contracted throughout the experiments. One possibility is that the diel release pattern is associated with diel patterns of algal division. Pre-dawn peaks in algal division frequencies have been observed in Stylophora pistillata, $P$. damicornis (Hoegh-Guldberg \& Smith 1989b), Montastrea annularis (Fitt et al. 1993) and Acropora formosa (Jones 1995). Dividing zooxanthellae may be separating into daughter cells during the light period and released.

Assessing changes in the zooxanthellae division frequency (measured by the number of cells appearing as doublets, MI) has been suggested as a potential means of assessing stress in corals (Brown 1988). The number of doublet cells in hospite was not significantly different between control and test solutions (Fig. 6). However, the number of cells appearing as doublets was 5 to $8 \times$ higher in the expelled population than in the tips at the end of the experiment (Fig. 6). A higher algal MI has also been observed in zooxanthellae expelled from sea anemones (Anemonia viridis, Zamani 1991, Suharsono \& Brown 1992; Anthopleura elegantissima, McCloskey et al. 1996).

If the algal MI increases markedly when the zooxanthellae are free from the host endodermal cells, then this introduces a considerable problem with the tissue stripping technique: using a WaterPik ${ }^{\mathrm{M}}$ to remove the tissues from a coral skeleton will produce an homogenate including both intracellular zooxanthellae, and extracellular zooxanthellae still within the coelenteron awaiting release (Suharsono \& Brown 1992). Corals in the process of losing zooxanthellae will have higher ratios of extracellular (more doublets cells) to intracellular zooxanthellae which may increase the $\mathrm{MI}$ of the algal population determined from an homogenate of the coral tissues. For example, in Anemonia viridis exposed to elevated water temperatures, the MI of zooxanthellae determined from slide preparations of tissues (i.e. a measurement of intracellular zooxanthellae division frequencies) was significantly lower than the MI of zooxanthellae determined from an homogenate technique (Suharsono \& Brown 1992).

Using the number of cells appearing as doublets to assess stress in corals using homogenate techniques clearly has a number of experimental and methodological problems. The algal $\mathrm{MI}$ is also higher in corals which have lost zooxanthellae following an external stress (Hoegh-Guldberg \& Smith 1989b, Fitt et al. 1993, Jones 1995) Thus both increases and decreases in the algal MI can occur during, and/or after an external stress, producing a generally obscured picture of the stress response.

Branch tips from the colony with lower algal densities (Test 1) discoloured to a greater extent during the 48 h toxicity tests, consistent with them having fewer zooxanthellae. However, a number of the branch tips exposed to $40 \mu \mathrm{g} \mathrm{l}^{-1}$ copper died, and all tips exposed to $80 \mathrm{\mu g} \mathrm{l}^{-1}$ copper died. No mortalities were observed during the toxicity test with the tips from the other colony (Test 2). Zooxanthellae have been suggested as sites for metal uptake in cnidarians (Buddemeier et al. 1981). Copper, cadmium and zinc accumulated in the zooxanthellae of the symbiotic anemone Anemonia viridis at levels 2 to $2.5 \times$ higher than those in the body of the anemone as a whole (Harland \& Nganro 1990, Harland et al. 1990). Zooxanthellae expulsion has also been suggested as a mechanism by which $A$. viridis could excrete metals and regulate metal concentrations (Harland \& Nganro 1990).

No measurements were made of the uptake and partitioning of copper during the toxicity tests described here. However, if metals preferentially accumulate in zooxanthellae, then corals with inherently higher algal densities may be more tolerant of elevated metal concentrations, or have a greater capacity for metal regulation through algal release. Interestingly, Harland \& Brown (1989) have observed that colonies of Porites Iutea collected from a reef-flat adjacent to a tin smelter and ore dressing plant in Thailand had higher algal 
densities than did control colonies collected away from any localised metal enrichment. Following exposure to elevated iron concentrations under laboratory conditions, the colonies with naturally higher densities did not lose zooxanthellae and had higher overall body burdens of iron. The results were interpreted as an example of acquired metal tolerance in colonies adjacent to the ore dressing plant. Differences in algal densities in colonies of Acropora formosa at Magnetic Island have been attributed to differences in the size of the algal symbionts between colonies (Jones 1995. Jones \& Yellowlees in press). Inherent differences in the algal densities between coral colonies, which may not necessarily be related to prior exposure to elevated metal levels, may therefore give the impression of an acquired metal tolerance.

During the present study, the effect of copper was only examined on 2 colonies (of 1 species), and consequently it is too early to recommend water quality criteria based upon the loss of zooxanthellae. However, the study has indicated that measuring loss of zooxanthellae from corals has considerable potential as a means of assessing stress. Significant effects were detected at copper concentrations of $5 \mathrm{ppb}$, a level similar to those reported in polluted tropical marine environments (Harland \& Brown 1989). The sensitivity of the bioassay compares favourably with other coelenterate bioassays, e.g. hydroid bioassays (Stebbing \& Brown 1984), where significant changes in reproductive output, enzyme activity and growth rates have been detected at copper concentrations of 0.1 to $>10 \mathrm{ppb}$. The technique can be used under controlled laboratory conditions and loss of zooxanthellae can be quantified using simple techniques. Day/night patterns of zooxanthellae loss observed during these studies indicate that starting times, and light levels, during future toxicity tests should be standardised. Intraspecific differences in algal densities between neighbouring colonies are likely to affect the outcome of experiments using loss of zooxanthellae to assess stress (or indeed any other physiological or biochemical responses) and must be adequately controlled for.

Acknowledgements Financial support was provided by a Great Barrier Reef Marine Parks Authority (GBRMPA) 'Augmentative Research Award' and the 1994 Australian Coral Reef Society (ACRS) 'Terry Walker' award.

\section{LITERATURE CITED}

Aceret TL, Sammarco PW, Coll JC (1995) Toxic effects of Alcyonacean diterpenes on scleractinian corals. J Exp Mar Biol Ecol 188:63-78

Brown BE (1988) Assessing the environmental impacts on coral reefs. Proc 6th Int Coral Reef Symp, Australia 1:71-87
Brown BE, Howard LS (1985) Assessing the effects of 'stress' on reef corals. Adv Mar Biol 22:1-63.

Brown BE, Le Tissier MDA, Dunne RP (1994) Tissue retraction in the scleractinian coral Coeloseris mayeri, its effect upon coral pigmentation, and preliminary implications for heat balance. Mar Ecol Prog Ser 105:209-218

Buddemeier RW, Schneider RC, Smith SV (1981) The alkaline earth chemistry of corals. Proc 4 th Int Coral Reef Symp. Philippines 2:81-85

Coles SL, Jokiel PL (1978) Synergistic effects of temperature, salinity and light on the hermatypic coral Montiporra verrucosa. Mar Biol 49:187-195

Denton GRW, Heitz LF (1990) Tridacna: sentinels of heavy metal pollution in Torres Strait waters - a critical evaluation. In: Lawrence D. Cansfield-Smith I (eds) Sustainable developments for traditional inhabitants of the Torres Strait region. Proceedings of the Torres Strait baseline study conference conducted by the Great Barrier Reef Marine Parks Authority, Cairns, p 311-331

Evans EC (1977) Microcosm responses to environmental perturbants. Helgol Meeresunters 30:178-191

Fitt WK. Spencer HJ, Halas J, White MW, Porter JW (1993) Recovery of Montastrea annularis in the Florida Keys after the 1987 Caribbean 'bleaching event' Coral Reefs 12: $57-64$

Gates R, Baghdasarian G, Muscatine L (1992) Temperature stress causes host-cell detachment in symbiotic cnidarians: implications for coral bleaching. Biol Bull (Woods Hole) 182:324-332

Gleason DF, Wellington GM (1993) Ultraviolet radiation and coral bleaching. Nature 365:838-839

Goreau TJ, MacFarlane AH (1990) Reduced growth rate of Montastrea annularis following the 1987-1988 coral bleaching event. Coral Reefs 8:211-215

Guzmán HM, Jiménez CE (1992) Contamination of coral reefs by heavy metals along the Caribbean coast of Central America. Mar Pollut Bull 24:554-561.

Harland AD, Brown BE (1989) Meta] tolerance in the scleractinian coral Porites lutea. Mar Pollut Bull 20:353-357

Harland AD, Bryan GW, Brown BE (1990) Zinc and cadmium absorption in the symbiotic anemone Anemonia viridis and the non-symbiotic anemone Actinia equina. J Mar Biol Ass UK 70:789-802

Harland AD, Nganro NR (1990) Copper uptake by the sea anemone Anemonia viridis and the role of zooxanthellae in metal regulation. Mar Biol 104:297-301

Hayes RL, Bush PG (1990) Microscopic observations of recovery in the reef-building scleractinian coral, Montastrea annularis, after bleaching on a Cayman reef. Coral Reefs 8:203-209

Hoegh-Guldberg O, McCloskey LR, Muscatine L (1987) Expulsion of zooxanthellae by cnidarians of the Red Sea Coral Reefs 5:201-204

Hoegh-Guldberg O, Smith GJ (1989a) The effects of sudden changes in light, temperature and salinity on the population density and export of zooxanthellae from the reef corals Seriatopora hystrix and Stylophora pistillata. J Exp Mar Biol Ecol 129:279-303

Hoegh-Guldberg O, Smith GJ (1989b) Influence of population density of zooxanthellae and supply of ammonium ions on the biomass and metabolic characteristics of the reef corals Seriatopora hystrix and Stylophora pistillata. Mar Ecol Prog Ser 57:173-186

Howard LS, Crosby DG, Alino P (1986) Evaluation of some of the methods for quantitatively assessing the toxicity of heavy metals to corals. Tech Rep, Hawaiian Institute of Marine Biology, Honolulu 37:452-464 
Jeffrey SW, Humphrey GF (1975) New spectrophotometric equations for determining chlorophylls $a, b, c$ and $c_{2}$ in higher plants, algae and natural phytoplankton. Biochem Physiol Pflanz 167:191-194

Johannes RE, Wiebe WJ (1970) Method for determination of coral tissue biomass and composition. Limnol Oceanogr $15: 822-824$

Jokiel PL, Coles SL (1977) Effects of temperature on the mortality and growth of Hawaiian reef corals. Mar Biol 43 $201-208$

Jones RJ (1995) Sublethal stress assessment in scleractinia and the regulatory biology of the coral-algal symbiosis. PhD thesis, James Cook University, Townsville

Jones RJ, Yellowlees D (in press) Regulation and control of intracellular algae (=zooxanthellae) in hard corals. Phil Trans R Soc Lond Ser B Biol Sci

JMP (1994) JMP statistics and graphics guide. SAS Institute Inc, Cary, NC

Kleppel GS, Dodge RE, Reese CJ (1989) Changes in pigmentation associated with the bleaching of stony corals. Limnol Oceanogr 34:1331-1335

Knap AH, Cook SB, Cook CB, Simmons JA, Jones RJ, Murray $A E$ (1991) Marine environmental studies to determine the impact of the mass burn incinerator proposed for Tynes Bay, Bermuda. Report prepared for the Ministry of Works and Engineering. Bermuda Biological Station for Reseach, Hamilton

Lesser MP, Shick JM (1989) Effects of irradiance and ultraviolet radiation on photoadaptation in the zooxanthellae of Aiptasia pallida: primary production, photoinhibition, and enzymatic defenses against oxygen toxicity. Mar Biol 102 $243-255$

McCloskey L, Cove TG, Verde EA (1996) Symbiont expulsion from the anemone Anthopleura elegantissima (Brandt) (Cnidaria; Anthozoa). J Exp Mar Biol Ecol 195:173-186

McConchie D, Harriott VJ (1992) The partitioning of metals between tissues and skeletal parts of corals: application in pollution monitoring. Proc 7 th Int Coral Reef Symp, Guam 1:97-103

Muscatine L, Grossman D, Doino J (1991) Release of symbi-

This article was submitted to the editor otic algae by tropical sea anemones and corals after cold shock. Mar Ecol Prog Ser 77:233-243

Oliver JK (1984) Intra-colony variation in the growth of Acropora formosa: extension rates and skeletal structure of white (Zooxanthellae-free) and brown-tipped branches Coral Reefs 3:139-147

Porter JW, Fitt WK, Spero HJ, Rogers CS, White MW (1989) Bleaching in reef corals: physiological and stable isotopic responses. Proc Natl Acad Scl USA 86:9342-9346

Stebbing ARD, Brown BE (1984) Marine ecotoxicological tests with coelenterates. In: Persoone $G$, Jaspers $E$, Claud $C$ (eds) Ecotoxicological testing for the marine environment. State University of Ghent, p 307-339

Stimson J, Kinzie RA (1991) The temporal release of zooxanthellae from the reef coral Pocillopora damicornis (Linnaeus) under nitrogen-enrichment and control conditions. J Exp Mar Biol Ecol 153:63-74

Stobart B (1994) Delimiting coral species using alternative techniques: Montipora digitata (Dana, 1846), a case study PhD thesis, James Cook University, Townsville

Suharsono, Brown BE (1992) Comparative measurements of mitotic index in zooxanthellae from a symbiotic cnidarian subject to temperature increase. J Exp Mar Biol Ecol 158: $179-188$

Szmant AM, Gassman NJ (1990) The effects of prolonged 'bleaching' on the tissue biomass and reproduction of the reef coral Montastrea annularis. Coral Reefs 8:217-224

Trench RK (1974) Nutritional potential in Zoanthus sociatus (Coelenterata, Anthozoa). Helgol Meeresunters 26: $174-216$

Wilkerson FP, Muller-Parker G, Muscatine L (1983) Temporal patterns of cell division in natural populations of endosymbiotic algae. Limnol Oceanogr 28:1009-1014

Yonge CM, Nicholls AG (1931) Studies on the physiology of corals. IV. The structure, distribution, and physiology of the zooxanthellae. Sci Rep Gt Barrier Reef Exped (19281929), p $135-176$

Zamani EP (1991) The use of mitotic indices of zooxanthellae as a marine bioassay. MSc thesis, University of Newcastleupon-Tyne

Manuscript first received: July 1, 1996

Revised version accepted: February 10, 1997 